\title{
Influence of Environmental Policies on China's Lead-Acid Battery Industry
}

\author{
Rongbo Zhang ${ }^{1}$, Zuo Cheng ${ }^{1}$, Ruirui Zhao ${ }^{1}$, Hongyu Chen ${ }^{1,2}$ and Yuehong Shu ${ }^{*}{ }^{1}$ \\ ${ }^{I}$ School of Chemistry and Environment, South China Normal University, Guangzhou 510006, PR China \\ ${ }^{2}$ Base of Production, Education \& Research on Energy Storage and Power Battery of Guangdong Higher Education \\ Institutes, Guangzhou 510006, PR China
}

\begin{abstract}
Frequently occurred "lead poisoning cases" in China have made the rapidly developing lead-acid battery industry a huge environmental harm in these years. Meanwhile, a series of related policies have been introduced by the Chinese government to inhibit the increasingly expanded effect by this industry on the environment. In this paper, the status of the lead-acid battery industry, including the demand, yield and growth rate, is discussed, along with the environmental regulation policies in this field as well as the secondary lead industry. Besides, this work also analyzes and discusses the specific content of the policies developed for environmental protection requirements and provides information on how enterprises can be properly prepared for the inspections and enter into compliance with the new regulations.
\end{abstract}

Keywords: Chinese policies, environmental inspection, lead-acid battery, lead poisoning.

\section{INTRODUCTION}

The urgent demand for energy in China promotes the development of traditional lead-acid battery greatly during recent years. Since nearly $98 \%$ of electric bicycles, electric motorcycles and electric tricycles now use lead-acid batteries as the power sources, the usage amount in these fields is higher than that in automotive field. In 2010, the number of lead-acid battery factories was around 2000, among which nearly 1600 factories have the production license whereas the rest didn't have. Over the years from 2009 to 2010, high level blood lead was detected in children, residents near the lead-acid batteries factories as well as the factory workers in many provinces. The State Department of Environmental Protection (DOEP) organized a full-scale rectification to the lead-acid battery factories and secondary lead factories around the whole country since March, 2011, and a series of policies related to environmental protection were issued at the same time.

A series of certifications including cleaner production, environmental protection and access condition checking were performed on the lead-acid battery factories and secondary lead factories by the present local government. The whole certification process should be finished by $31^{\text {st }}$ December 2015, and the enterprises without passing the certifications will be closed since the beginning of January 2016.

In this paper, the present status of the lead-acid battery factories and secondary lead factories and the influence on these enterprises of the issued policies, especially the environmental protection part, have been summarized and analyzed in detail.

*Address correspondence to this author at the School of Chemistry and Environment, South China Normal University, Guangzhou 510006, PR China; E-mail: hongershu@163.com

\section{METHODS}

We conducted the literature search mainly through the website of the ministry of environmental protection, as well as some News net.

\section{RESULTS}

\subsection{Development of Lead-Acid Battery Enterprises in} China

Even with the lead-acid battery industry in China under constant review and undergoing significant policy reform by the national government, lead-acid batteries are still the fastest growing chemical power sources in China (Table 1). According to statistics, lead-acid battery production in China has not diminished, even with the introduction of much stricter environmental protection policies instituted by the

Table 1. China's battery production output distribution in 2013.

\begin{tabular}{|c|c|c|}
\hline Species & $\mathbf{2 0 1 3}$ & Year on Year \\
\hline \hline Nickel-cadmium battery $\left(\times 10^{8}\right)$ & 3.86 & $4 \%$ decline \\
\hline Nickel hydrogen battery $\left(\times 10^{8}\right)$ & 8.55 & $9 \%$ decline \\
\hline Lithium-ion battery $\left(\times 10^{8}\right)$ & 25.3 & $10 \%$ increase \\
\hline Lead-Acid battery $\left(\times 10^{4} \mathrm{kVAh}\right)$ & 18529 & $12 \%$ increase \\
\hline Zinc-manganese battery $\left(\times 10^{8}\right)$ & 196 & $5 \%$ increase \\
\hline Alkaline manganese battery $\left(\times 10^{8}\right)$ & 120 & $10 \%$ increase \\
\hline Primary lithium battery $\left(\times 10^{8}\right)$ & 25 & $9 \%$ increase \\
\hline
\end{tabular}

2015 Bentham Open 
Chinese government. Instead the industry has been maintaining an $18 \%$ growth rate over the last decade. The industry's production output since 2002 is shown in Fig. (1) and the production distribution of Chinese lead-acid batteries in terms of applied use in 2013 is shown in Fig. (2).

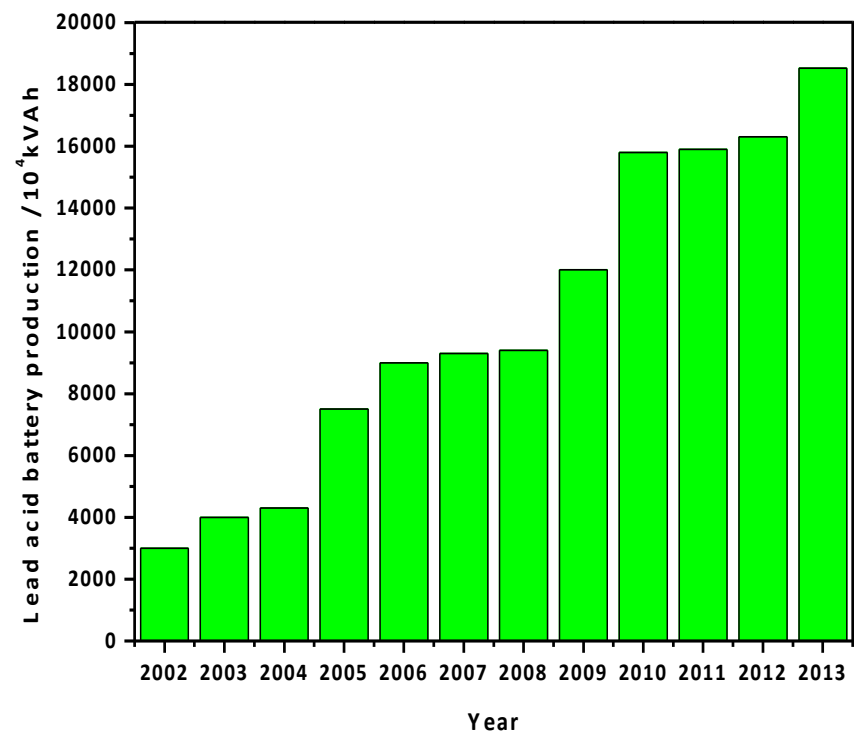

Fig. (1). Lead-acid battery production output in China.

The rapid development of passenger and low-speed electric vehicles has caused an incredible demand for leadacid batteries (as shown in Table 2) and driven the fast growth in lead-acid battery production. Table $\mathbf{3}$ shows the lead-acid battery demand, lead consumption and the recycled lead movement from recycling waste lead-acid batteries in China according to the China Battery Industry Association's analysis and forecast.

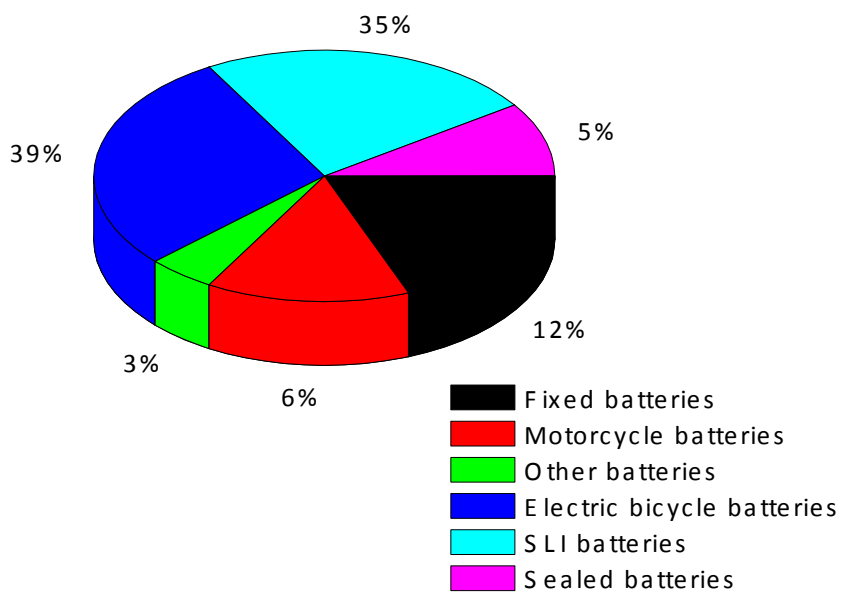

Fig. (2). Production distribution of lead-acid batteries in 2013.

\subsection{Influence of National Environmental Protection Policies on the China's Lead-Acid Battery Industry}

The enactment of a special action to introduce new environmental policies for the lead-acid battery industry was launched in March 2011. From statistics gathered as a result of the new polices, the government identified 1949 verified enterprises in China as of November 30, 2011 that existed before the legislation came into effect, consisting of 1772 lead-acid battery enterprises and 177 recycled lead enterprises. The 1772 lead-acid battery enterprises were primarily distributed in Jiangsu, Zhejiang, Guangdong and Shandong, as shown in Fig. (3).

While this was an extremely large number of enterprises, many of the businesses that existed prior to November 2011 were small and with very little production capacity, with

Table 2. Demand for lead-acid batteries in different markets of China in 2013.

\begin{tabular}{|c|c|c|c|}
\hline Market & Car Ownership & New Increment & Battery Demand Growth \\
\hline \hline Car & $1.04 \times 10^{8}$ & $1850 \times 10^{4}$ & $18.50 \%$ \\
\hline Low-speed electric vehicle & $35 \times 10^{4}$ & $30 \times 10^{4}$ & $85.71 \%$ \\
\hline Motorcycle & $1.02 \times 10^{8}$ & $2700 \times 10^{4}$ & $26.47 \%$ \\
\hline Electric bicycle & $1.47 \times 10^{8}$ & $3000 \times 10^{4}$ & $21.43 \%$ \\
\hline Communication station & $135 \times 10^{4}$ & $14 \times 10^{4}$ & $10.3 \%$ \\
\hline
\end{tabular}

Table 3. Lead consumption and recycled lead movement of lead-acid batteries in China.

\begin{tabular}{|c|c|c|c|}
\hline Year & Demand (10 $\mathbf{k}$ VAh) & Lead Consumption (10 ${ }^{\mathbf{4}}$ Ton) & Predict Recycled Lead (10 $\mathbf{~ t o n})^{2}$ \\
\hline \hline 2009 & 12000 & 305 & 124 \\
\hline 2010 & 13500 & 313 & 179 \\
\hline 2011 & 15100 & 300 & 193 \\
\hline 2012 & 16900 & 332 & 212 \\
\hline $2013 \mathrm{e}$ & 19000 & 372 & 240 \\
\hline $2014 \mathrm{e}$ & 21300 & 418 & 269 \\
\hline $2015 \mathrm{e}$ & 23900 & 469 & \\
\hline
\end{tabular}




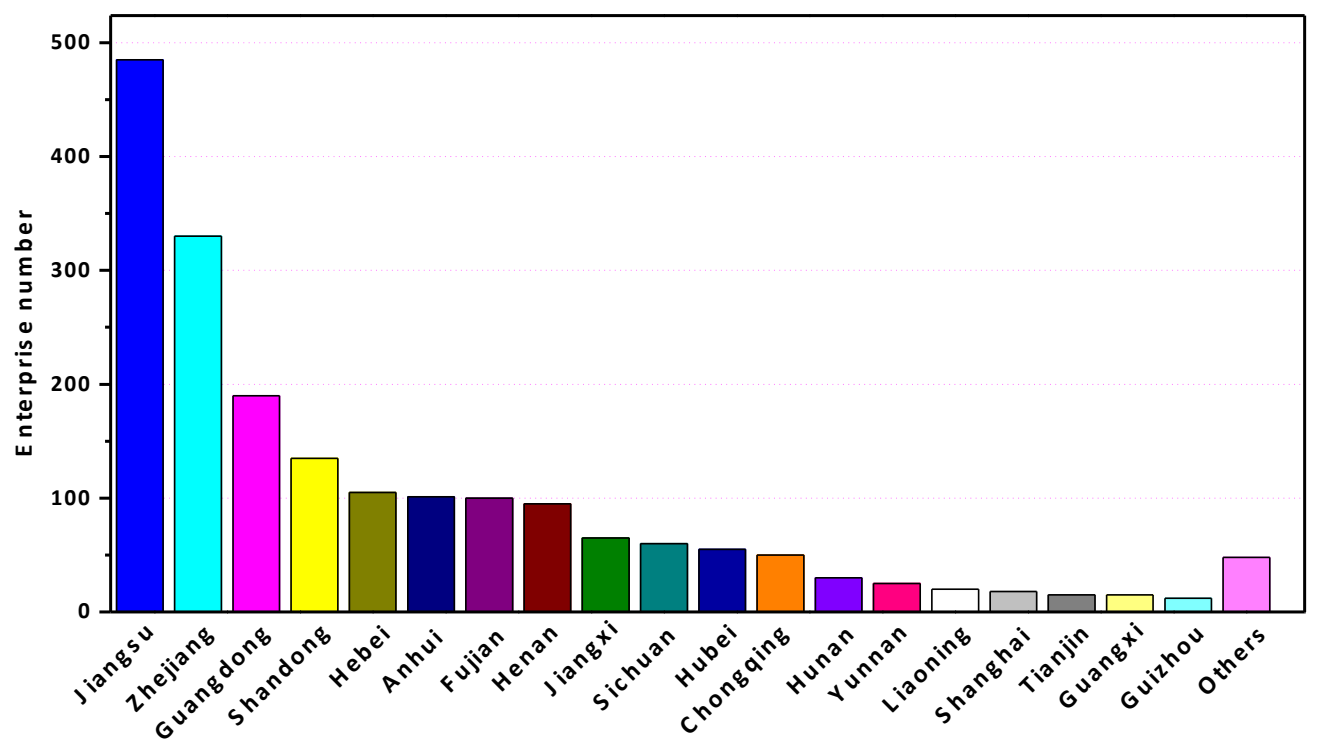

Fig. (3). Lead-acid battery enterprises by province before environmental regulation in 2011.

some enterprises making use of poor production equipment and protection facilities. Furthermore, many individual enterprises did not have environmental protection facilities, and discharged lead pollution directly into the environment, which meant that lead pollution accidents occurred quite frequently.

The total lead-acid battery output from the top 300 enterprises have already accounted for $80 \%$ of total output from China's lead-acid battery [1]. However, the total output of 1472 enterprises after the top 300, accounted only for $20 \%$ of total output from China's lead-acid battery, as shown in Fig. (4).

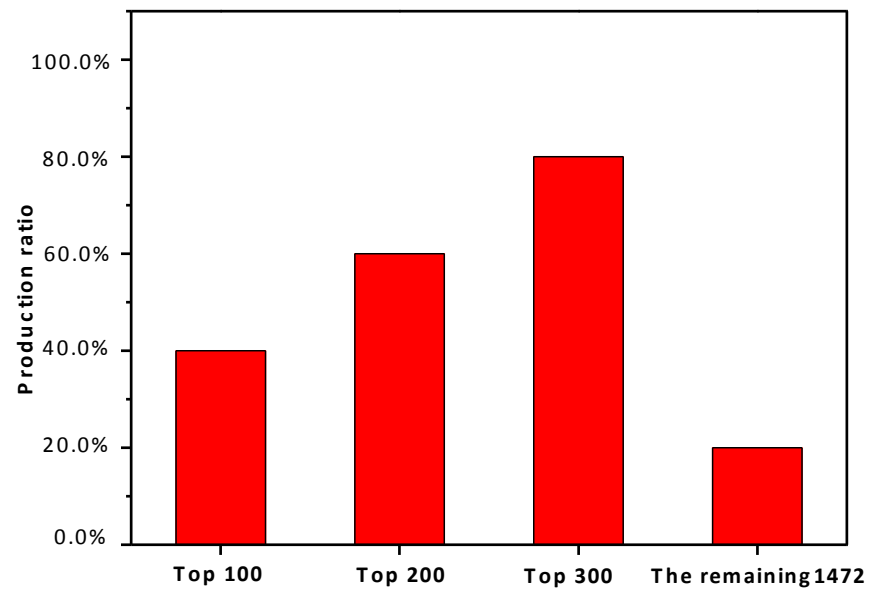

Fig. (4). Productivity distribution of lead-acid battery enterprises before environmental regulation.

This excess of widely distributed lead-acid battery enterprises in China meant that environmental protection policy was virtually impossible to enforce. On November 30, 2011 , the national government issued a total of 1772 leadacid battery production licenses, even though only 292 enterprises qualified for those licenses in terms of the environmental protections they provided, i.e. a qualification rate of only $16.48 \%$. From these numbers, it is clear that the existing system to manage lead-acid battery production licenses had problems, and the previous management scheme had helped to promote the large number, small size and wide distribution of enterprises, most of whom had only low production capacity, unreasonable industrial distribution and considerable negative environmental impact.

Between 2009 and 2011, the high frequency of blood lead poisoning accidents attracted considerable attention from both the Chinese government and the media. Since early 2011, the Chinese government began its overall rectification of the China's lead-acid battery industry and secondary lead industry. A series of policies were made to rectify China's lead-acid battery industry and secondary lead industry [2]; the main policies and measures are shown in Table 4.

Once the Chinese government formulated and enforced a series of policies for the China's lead-acid battery industry and secondary lead industry, the number of lead-acid battery enterprises sharply declined throughout China, particularly in Jiangsu Province which had the largest number of enterprises. The situation of Jiangsu province after environmental rectification is shown in Fig. (5).

Nationally, the number of lead-acid battery enterprises in China dropped from 1772 before the country's environmental rectification to just 450 at the end of 2013. The present output relies primarily on these 450 enterprises, as shown in Table 5 .

\subsection{The Chinese Lead-Acid Battery Industry Encounters Difficulties with the New Environmental Policies}

To meet the standards developed for the lead-acid battery industries and secondary lead industries issued by the Ministry of Industry and Information Technology, the Environment Ministry and three other Ministries on March 12,2013 , all lead-acid battery enterprises and secondary lead enterprises throughout China are expected to undergo a thorough environmental inspection organized by the Environmental Department, as well as an admission 
Table 4. Environmental reform campaign of the Chinese lead-acid battery industry.

\begin{tabular}{|c|c|c|}
\hline Mar 2011 & Environmental Department & $\begin{array}{l}\text { The Environmental Supervision Bureau issues an on-site } \\
\text { environmental supervision guide for the lead-acid battery industry } \\
\text { (draft). }\end{array}$ \\
\hline Feb. 20, 2011-Mar. 10, 2011 & Environmental Department & $\begin{array}{l}\text { The Environmental Department and local Environmental } \\
\text { Supervisory Departments are divided into } 11 \text { groups to coordinate } \\
\text { on-site environmental supervision of enterprises; the Battery } \\
\text { Association assigns someone to coordinate the process. }\end{array}$ \\
\hline Mar. 28, 2011 & Environmental Department & $\begin{array}{l}\text { Nine national ministries hold a video conference on the } \\
\text { environmental campaign to reform the lead-acid battery industry, } \\
\text { with } 72000 \text { people attending. }\end{array}$ \\
\hline Mar. 2011 & Environmental Department & $\begin{array}{l}\text { The Environmental Supervisory Departments of Zhejiang, Shandong, } \\
\text { Anhui and Guangdong Provinces conduct a thorough investigation of } \\
\text { the lead-acid battery industries and recycled lead industries, shutting } \\
\text { down all unqualified enterprises. }\end{array}$ \\
\hline July 30, 2011 & Environmental Department & $\begin{array}{l}\text { The Environmental Department issues its first public status list of } \\
\text { lead-acid battery enterprises and recycled lead enterprises. }\end{array}$ \\
\hline Aug. 2011- Dec. 2011 & $\begin{array}{l}\text { Ministry of Industry and Information } \\
\text { Technology }\end{array}$ & $\begin{array}{l}\text { The Ministry of Industry and Information Technology mandates the } \\
\text { Battery Association to investigate and formulate a list of outdated } \\
\text { low-capacity production techniques within the lead-acid battery } \\
\text { industry. }\end{array}$ \\
\hline Nov. 30, 2011 & Environmental Department & $\begin{array}{l}\text { The Environmental department issues its second public status list of } \\
\text { lead-acid battery enterprises and recycled lead enterprises. }\end{array}$ \\
\hline Dec. 2011 & Ministry of Health & $\begin{array}{l}\text { Formulates an occupational health standard for the lead-acid battery } \\
\text { industry. }\end{array}$ \\
\hline May 11,2012 & $\begin{array}{l}\text { Ministry of Industry and Information } \\
\text { Technology, Environmental Department }\end{array}$ & $\begin{array}{l}\text { The Ministry of Industry and Information Technology and the } \\
\text { Environmental Department issue new conditions for manufacturers } \\
\text { to operate as part of the lead-acid battery industry. }\end{array}$ \\
\hline Jun. 30, 2012 & Environmental Department & $\begin{array}{l}\text { The Environmental department issues the third public status list of } \\
\text { lead-acid battery and recycled lead enterprises. }\end{array}$ \\
\hline Sep. 5, 2012 & $\begin{array}{l}\text { Ministry of Industry and Information } \\
\text { Technology, Environmental Department }\end{array}$ & $\begin{array}{l}\text { The Ministry of Industry and Information Technology and the } \\
\text { Environmental Department issue new conditions for manufacturers } \\
\text { to operate as part of the lead-acid battery industry. }\end{array}$ \\
\hline Sep. 21, 2012 & Finance Department & $\begin{array}{l}\text { In order to curb their environmental impact, the government levees a } \\
5 \% \text { battery consumption tax, which includes lead-acid batteries. }\end{array}$ \\
\hline Oct. 8,2012 & $\begin{array}{l}\text { Environmental Department, National } \\
\text { Development and Reform Commission, } \\
\text { Ministry of Industry and Information } \\
\text { Technology, Ministry of Health }\end{array}$ & $\begin{array}{l}\text { Environment and Development [2012]123, issues its Hazardous } \\
\text { Wastes Control Program as part of the Twelfth Five-Year Plan, } \\
\text { which involves construction of a national recycling system for waste } \\
\text { lead-acid batteries and the development of market regulations for } \\
\text { recycled lead. }\end{array}$ \\
\hline Nov. 8,2012 & Environmental Department & $\begin{array}{l}\text { The first batch of enterprises apply for material verification; } 17 \\
\text { enterprises apply as part of this first group. }\end{array}$ \\
\hline Nov. 29, 2012 & $\begin{array}{l}\text { Ministry of Industry and Information } \\
\text { Technology, Environmental Department }\end{array}$ & $\begin{array}{c}\text { The Ministry of Industry and Information Technology publishes } \\
\text { interim consumption management measures for the lead-acid battery } \\
\text { industry [2012]509. }\end{array}$ \\
\hline Nov. 30, 2012 & Environmental Department & $\begin{array}{l}\text { The Environmental Department seeks advice concerning lead-acid } \\
\text { battery production and renewable pollution control techniques } \\
\text { (exposure drafts). }\end{array}$ \\
\hline
\end{tabular}




\begin{tabular}{|c|c|c|}
\hline Time & Organizer & Project Content \\
\hline Nov. 30, 2012 & Environmental Department & $\begin{array}{l}\text { The Environmental Department issues the fourth iteration of its pubic } \\
\text { status list of lead-acid battery enterprises. }\end{array}$ \\
\hline Jan. 2013 & Environmental Department & $\begin{array}{l}\text { Issues a public notice identifying the } 12 \text { lead-acid battery enterprises } \\
\text { selected for the first batch of environmental inspections. }\end{array}$ \\
\hline Mar. 12, 2013 & $\begin{array}{l}\text { Ministry of Industry and Information } \\
\text { Technology, Environmental Department, } \\
\text { Commerce Department, Development and } \\
\text { Reform Commission, Finance Department }\end{array}$ & $\begin{array}{c}\text { The Ministry of Industry and Information Technology issues an } \\
\text { Opinion concerning lead-acid battery industry and recycled lead } \\
\text { industry development promotion [2013] } 92 \text {. }\end{array}$ \\
\hline Mar. 16, 2013 & Environmental Department & $\begin{array}{l}94 \text { enterprises apply for material verification in the second batch of } \\
\text { environmental inspections. }\end{array}$ \\
\hline Apr. 16, 2013 & Environmental Department & $\begin{array}{l}\text { The Environmental Department publicly announces that ten of the } \\
\text { lead-acid battery enterprises from the first batch of enterprises have } \\
\text { completed their environmental inspection. }\end{array}$ \\
\hline Nov. 20, 2013 & $\begin{array}{l}\text { Ministry of Industry and Information } \\
\text { Technology }\end{array}$ & $\begin{array}{l}\text { The Ministry of Industry and Information Technology publicly } \\
\text { announces that six lead-acid battery enterprises from the first batch } \\
\text { of inspections have passed their operating permit inspection. }\end{array}$ \\
\hline Dec. 17,2013 & Environmental Department & $\begin{array}{l}\text { The Environmental Department publicly announces that } 12 \text { lead-acid } \\
\text { battery enterprises and } 2 \text { recycled lead enterprises from the second } \\
\text { batch of enterprises have completed their environmental inspection. }\end{array}$ \\
\hline Mar. 18, 2014 & $\begin{array}{c}\text { Ministry of Industry and Information } \\
\text { Technology }\end{array}$ & $\begin{array}{l}\text { Begins on-site minimum operating conditions inspection of the } 12 \\
\text { lead-acid battery enterprises and } 2 \text { recycled lead enterprises that have } \\
\text { passed their environmental inspection. }\end{array}$ \\
\hline
\end{tabular}

Table 5. Number and output of Chinese lead-acid battery enterprises after environmental reform.

\begin{tabular}{|c|c|c|c|c|}
\hline Year & Number of Manufacturers & Nameplate Capacity (104 kVAh) & Assembly Capacity (10 $\left.{ }^{\mathbf{4}} \mathbf{k V h}\right)$ & Battery Output (104 $\mathbf{k V A h )}$ \\
\hline \hline July 30, 2011 & 229 & 10865 & 15069 & 15432 \\
\hline Nov. 30, 2011 & 291 & 13460 & 14485 & 14230 \\
\hline Jun. 30, 2012 & 373 & 14079 & 26017 & 17486 \\
\hline Nov. 30, 2012 & 398 & 22335 & 30292 & 18529 \\
\hline Nov. 30, 2013 & 450 & 25053 & \\
\hline
\end{tabular}

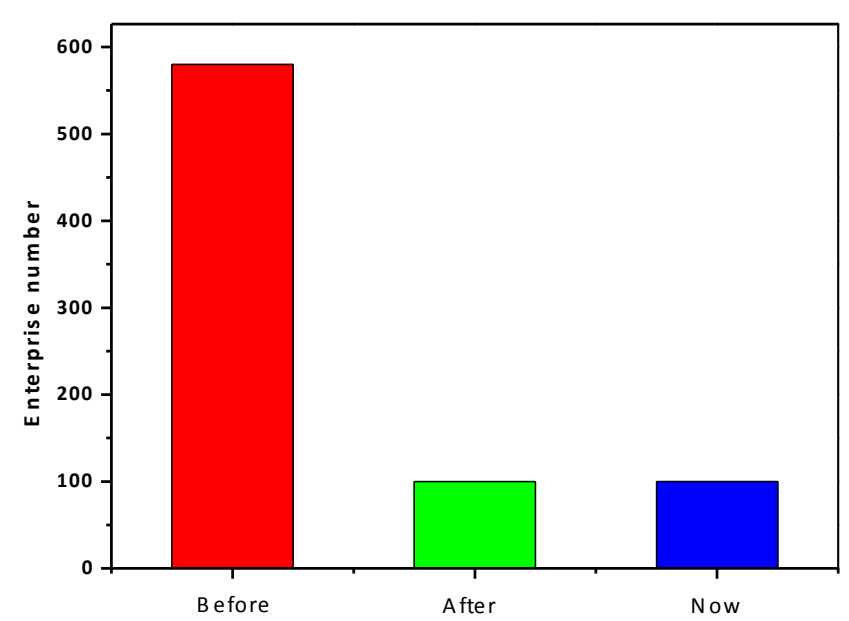

Fig. (5). lead-acid enterprise numbers in Jiangsu province before and after environmental regulation.

inspection organized by the Ministry of Industry and Information Technology before December 31, 2015. The
Environmental Department issued its notice to carry out environmental inspections of lead-acid battery enterprises and secondary lead enterprises on March 19, 2012, while the Ministry of Industry and Information Technology and the Environmental Ministry issued their access conditions for lead-acid battery manufacturers on May 11, 2012 and access conditions for the secondary lead industry on September 5, 2012. However, progress in terms of the number of enterprises who have completed the access process has been very slow. Table 6 shows the number of lead-acid battery enterprises and secondary lead enterprises who have completed each stage of the process.

The only foreign enterprise that completed its environmental protection inspection and received and passed all access conditions in the first batch of enterprises was the East Penn (Wujiang) Battery Co., Ltd., and the only enterprise in the second batch was Apollo Battery Co., Ltd. In fact, there were more than 20 foreign enterprises in China, as shown in Table 7.

These foreign lead-acid battery enterprises possess stateof-the-art production equipment and environmentally sound 
Table 6. Number of enterprises who have completed the environmental inspection issued by the Environmental Ministry and met all permits to operate conditions issued by the Ministry of Industry and Information Technology.

\begin{tabular}{|c|c|c|c|c|c|}
\hline Batch & Start Time & $\begin{array}{c}\text { First Step: Number of } \\
\text { Environmental Inspection } \\
\text { Applications }\end{array}$ & $\begin{array}{l}\text { Second Step: Number of } \\
\text { Enterprises Who } \\
\text { Completed the } \\
\text { Environmental } \\
\text { Inspection }\end{array}$ & $\begin{array}{c}\text { Third step: NUMBER of } \\
\text { Applications for an } \\
\text { Operating Permit }\end{array}$ & $\begin{array}{c}\text { Fourth Step: Number of } \\
\text { Enterprises Who Passed } \\
\text { All Operating } \\
\text { Conditions }\end{array}$ \\
\hline $\begin{array}{l}\text { First } \\
\text { batch }\end{array}$ & Nov.8, 2012 & 17 & $\begin{array}{c}10 \text { (announced on Apr. } \\
16,2013 \text { ) }\end{array}$ & 9 & $\begin{array}{c}6 \text { (announced on Nov. 20, } \\
2013 \text { ) }\end{array}$ \\
\hline $\begin{array}{l}\text { Second } \\
\text { batch }\end{array}$ & Mar.16, 2013 & 94 & $\begin{array}{c}14 \text { (includes } 2 \text { recycled } \\
\text { lead enterprises) } \\
\text { announced on Dec.17, } \\
2013\end{array}$ & $\begin{array}{l}10 \text { (includes } 2 \text { recycled } \\
\text { lead enterprises) }\end{array}$ & $\begin{array}{c}\text { 7( announced in June. 23, } \\
2014\end{array}$ \\
\hline
\end{tabular}

Table 7. Foreign lead-acid battery enterprises in China.

\begin{tabular}{|c|c|}
\hline Company Name & Site \\
\hline Enersys & Shenzhen, Yangzhou, Chongqing, Chaozhou \\
\hline Johnson Controls & Shanghai, Zhejiang Changxing, Chongqing \\
\hline Haze & Shenzhen \\
\hline$C \& D$ & Shanghai \\
\hline $\mathrm{B} \& \mathrm{~B}$ & Raoping, Changsha \\
\hline GS Yuasa & Tianjin, Zhangqiu, Shunde, Wuxi \\
\hline Panasonic & Shenyang \\
\hline Hoppecke & Wuhan, Shanghai, Beijing \\
\hline Ricun & Changzhou \\
\hline Apollo & Yangzhou \\
\hline Toplite & Guangzhou \\
\hline
\end{tabular}

production facilities; however, most did not apply for the environmental inspection or the necessary operating permit because of their failure to understand the new Chinese environmental policies. In fact, all lead-acid battery enterprises and secondary lead battery enterprises had to accomplish the following three standard steps in order to undergo environmental protection inspection and access conditions before Dec.31, 2015 [3].

i) The first step is to undergo a clean production audit organized by the Environmental Department of the region, and this audit must be conducted every two years. Experts provided by the regional Environmental Department shall determine whether an enterprise meets the required level of recycling and cleaner production and the enterprises should reach secondary level of cleaner production.

ii) The second step is to pass an environmental inspection organized by the National Environmental
Department, formal announcement of National Environmental Department shall prevail.

iii) The third step is to pass access conditions inspection organized by the National Ministry of Industry and Information Technology. However, an enterprise must pass the environmental inspection prior to applying for this permit inspection.

After more than a year of work to move the new inspection process forward, it was clear that the pass rate for the second step (the environmental protection inspection) is very low, and this step for most enterprises dragged out for a very long time. There were 94 enterprises who had applied for an environmental protection inspection in the second batch of enterprises, out of which only 27 enterprises entered the public stage of the process, among which only 14 enterprises completed the entire inspection and could publicly announce that they had passed the inspection. In the third batch of enterprises, 32 enterprises entered the public stage and 26 enterprises passed the inspection. It seems that 
most Chinese lead-acid battery enterprises-and this includes foreign enterprises within China-have not yet mastered the logistics and necessary paperwork required for the environmental protection inspection or understand how to meet all the new operating conditions now required for the lead-acid battery industry [4].

The purpose of this paper is to provide a comprehensive description of the environmental protection inspection requirements and all necessary operating conditions for leadacid battery enterprises in China so that competitors in the industry, particularly foreign enterprises, can fully understand the necessary details and so pass all the necessary steps to receiving an operating permit. The government's objective was to have 300-500 lead-acid battery enterprises in China by the end of 2015; this means the remaining number of current competitors will be eliminated.

\section{CONCLUSION}

Although Chinese government has shut down most of lead-acid battery factories and secondary lead factories, the output in this field hasn't decreased due to the production scale expansion of the existing factories.

It has been estimated that only 100-200 factories will pass the environmental protection inspection and access condition audit performed onto the factories planned to finish before December, $31^{\text {th }}, 2015$, which has been attributed to the strict vetting conditions and slow speed.

\section{CONFLICT OF INTEREST}

The authors confirm that this article content has no conflict of interest.

\section{ACKNOWLEDGEMENTS}

This work was funded by the Production, Education \& Research Combining Project of Guangdong Province and the Ministry of Education (No. 2011B090400560), the Science and Technology Project of Guangzhou (No. 11A92091438) and the Science and Technology Project of Panyu District (No. 2010-zhuan-12-2).

\section{REFERENCES}

[1] Wang, J. Access Inspection of Lead-Acid Battery Industry: HighLevel Training Meeting of Access Technology and Management for Lead-Acid Battery Industry, Jiangxi Nanchang, September 3 to 5, 2013.

[2] Cao, G. Current State and Developing Trend of Lead-Acid Battery Market, Training Meeting of Environmental Inspection for LeadAcid Battery Industry, Anhui Huangshan, May 8 to 9, 2013.

[3] Zhao, J. Training Materials of Environment Inspection for LeadAcid Battery and Secondary Lead Industry, Anhui Huangshan, May 8 to $9,2013$.

[4] Lead-Acid Battery Enterprise Environmental Verification SelfInspection Report, Pollution Prevention Division of Environmental Department, June, 2012. 